\title{
Choroidal and Ciliary Body Melanoma pT3b TNM Finding v8
}

National Cancer Institute

\section{Source}

National Cancer Institute. Choroidal and Ciliary Body Melanoma pT 3b TNM Finding v8. NCI Thesaurus. Code C140643.

Choroidal and ciliary body melanoma, tumor size category 3 with ciliary body involvement. (from AJCC 8th Ed.) 